\section{Búzaminták fungicid szermaradvány ellenőrzése és gombafertőzöttségének kimutatása}

\author{
Soós József - Fehér László - Rigó Krisztina - \\ Tanács Lajos
}

Szegedi Tudományegyetem, Szegedi Élelmiszeripari Főiskola, Élelmiszertudományi Tanszék, Szeged

\section{ÖSSZEFOGLALÁS}

A búzát veszélyeztetö gombás betegségek elleni vegyszeres védekezés nagyon fontos feladat, hiszen a fertözött szemek toxin szennyezettsége állati- és humánegészségügyi vonatkozásban egyaránt veszélyes, de hasonlóan fontos ismeret az alkalmazott vegyszerek lehetséges maradványainak jelenléte. Háromirányú vizsgálatokat végeztünk arra vonatkozóan, hogy a szegedi Gabonakutató Kht. kontroll és fungicidekkel állománykezelt termésmintáiban kimutathatóak-e fungicid nyomok (gázkromatográfia, GC), illetve a gombafertözöttség mértékét ellenöriztük ergoszterin tartalom (mikrohullámú feltárás és folyadékkromatográfia, HPLC) alapján és közvetlen mikrobiológiai tenyésztéssel. A 2000-ben kezelt gabonamintákban fungicid nyomokat már nem találtunk (november), az ergoszterin tartalom és közvetlen mikrobiológiai elemzés jó minőséget és nagyon alacsony gombaszennyezettséget mutatnak, mig a csapadékos 1999-es év mikrobiológiai adatai rosszabbak.

\section{SUMMARY}

To protect crops with chemicals against different microorganisms are very important because residues of toxins could pollute infected grains. This could have the meaning of serious danger to the human and animal health. Similarly important is knowledge of details about presence or absence of any practically applied protective compounds. Experimental studies were performed on fungicide treated cereals of the Cereal Research Non-Profit Company, Szeged. Chromatographic methods were used (GC and some GC-MS) to find low level fungicide residues, microwave-assisted isolation of ergosterol was followed by HPLC to detect possible fungal infections and a more detailed microbiological analysis completed the work. Concerning the dry year 2000, no fungicides were found in the samples (by November), the ergosterol level was found to be less than $8 \mathrm{ppm}$, meaning good quality, coupled with an extremely low level of fungal infections. This was confirmed by direct microbiological testing. In comparison with the microbiological results from 1999, a negative difference can be recognized, most probably due to the rainy weather throughout the year.

\section{ANYAGOK ÉS MÓDSZEREK}

\subsection{A szántóföldi kísérletek körülményei}

A szántóföldi kisparcellás kísérleteket a Gabonatermesztési Kutató Kht. öthalmi telepén állították be, mélyben sós réti csernozjom talajon (uralkodó kőzetanyaga lösz), amelynek átlagos kémhatása $\mathrm{pH} 7,9$; humusztartalma 2,7-3,6\%; Nszolgáltató képessége közepes; foszfor és kálium ellátottsága jó - igen jó.
A közvetlen mikrobiológia vizsgálatokkal átfedő kísérletek időszaka meteorológiai szempontból egy csapadékos (1999.) és egy száraz (2000.) évböl állt. $\mathrm{Az}$ 1998/99. évi tenyészidőben $645 \mathrm{~mm}$, az 1999/2000-éviben $340 \mathrm{~mm}$ csapadék hullott. Höösszegben mindkét periódus melegebb volt, mint a sokévi átlag. A kísérleteinket véletlen blokk elrendezésben -4 ismétléssel $-10 \mathrm{~m}^{2}$-es parcellákon állították be. Az elővetemény mindkét évben borsó volt, amely után alaptrágyaként $60+60+60 \mathrm{~kg} / \mathrm{ha}$ NPK hatóanyagot juttattak $\mathrm{ki}$ a területre. A gyomirtást tavasszal Granstar $15 \mathrm{~g} / \mathrm{ha}$ adagjával végezték el.

\subsection{A vizsgált fajták és alkalmazott fungicidek}

Összesen 4 búzafajtát állítottak kísérletbe, amelyek származás, érésidő és betegség-ellenállóság szempontjából egyaránt eltérőek. A korai éréscsoportból a GK Sára (standard) és GK Garaboly a levélbetegségekre és a kalászfuzáriózisra közepesen fogékony, a középérésü GK Miska kissé fogékony, a GK Petur pedig ellenálló fajta. 2 éves kísérleti időszakban összesen 5 fungicidnek produktivitásra gyakorolt hatásait vizsgálták. A kezelések közül az Amistar dózisát korábbi időpontban (2. nódusz megjelenése) a többi gombaölő szert később (kalászhányás) permetezték, 400 1/ha vízmennyiség alkalmazásával. A vegyszereket törzsoldatból, hígítási sorozattal készítették elő a kezelésekhez (Tanács és mtsai, 1997). A gázkromatográfiás szermaradvány és az ergoszterin vizsgálatokhoz a 2000. tavaszi kezelések GK Sára és GK Miska mintáit használtuk az elöbbi sorokból. Lényeges, hogy a szermaradványok kivonása a jelzett év novemberének második, illetve december első felében történt.

\subsection{Az ergoszterin vizsgálatok körülményei}

\subsubsection{A használt anyagok}

Ergoszterin (Sigma); acetonitril, metanol (HPLC minõségü, Carlo Erba); n-pentán, n-hexán, metanol, kálium-hidroxid, nátrium-hidroxid alt. (Reanal).

\subsubsection{A mikrohullámú feltárás (Young, 1995) és a folyadékromatográfia körülményei}

A különböző búzaminták penész-fertőzöttségének megállapításához az ergoszterin vizsgálatra történő kinyerését mikrohullámú kezeléssel lúgos metanolos közegben végeztük (Szabó és mtsai, 2000). A búzamintákból $\mathrm{kb}$. $30 \mathrm{~g}$ mennyiséget daráltunk le úgy, hogy a darába a korpa is belekerüljön. A 
búzadarából a mikrohullámú feltáráshoz $0,25 \mathrm{~g}$ mennyiségeket mértünk ki. Az előkészített mintákhoz teflon-bombacsőben 2,0 ml metanolt és $0,5 \mathrm{ml} 2 \mathrm{M} \mathrm{KOH}$ oldatot adtunk, majd mikrohullámú kezelésnek vetettük alá. A professzionális mikrohullámú készülék LABOTRON 500 típusú volt $\left(P_{\max }=500 \mathrm{~W}, \quad U=220 \mathrm{~V}, f=2450 \mathrm{MHz}\right.$, vákumozható, kombinált energiaközlésre alkalmas). A kezelés 90 másodpercig tartott, majd a teflonbomba-csöveket szobahőmérsékletüre hütöttük, az elegyet $1 \mathrm{ml} 1 \mathrm{M} \mathrm{HCl}$ oldattal semlegesítettük. A mintákhoz $1 \mathrm{ml}$ n-hexánt adtunk, amivel azokat átmostuk centrifugacsövekbe. Az extrakcióhoz a mintákat kémcsőkeverővel 1 percig kevertük, a fázisok szétválasztását centrifugálással végeztük el 7000 fordulat/perc (Sorwall RC-5B) fordulatszámot alkalmazva. A minta felülúszóját - ami az ergoszterint tartalmazza - elválasztottuk és porceláncsészékben összegyüjtöttük. Az extrakciót háromszor 1 ml n-hexánnal végeztük. A csészékben összegyüjtött szerves fázist egy éjszakán át bepároltuk, majd folyadék-kromatográfiával határoztuk meg a minták ergoszterin tartalmát (HP 1090 Series II típusú HPLC készülék, diódasoros UV detektorral, Pentium II Celeron 466 típusú számítógéppel, HP Chemstation szoftvervezérléssel, izokratikus elúció: acetonitril:metilalkohol 8:2, v = $1,5 \mathrm{ml} / \mathrm{min}, \mathrm{V}_{\text {inj }}=5 \mu \mathrm{l}$ ).

\subsection{A mikrobiológiai vizsgálatok körülményei} (Schnürer, 1995)

1.4.1. Az alkalmazott Fusarium szelektív PCNBtápközeg összetétele $\left(1000 \mathrm{~cm}^{3}\right.$ meleg desztillált vizben feloldva)

Pepton $15 \mathrm{~g}+\mathrm{KH}_{2} \mathrm{PO}_{4} 1 \mathrm{~g}+\mathrm{MgSO}_{4} \times 7 \mathrm{H}_{2} \mathrm{O}$ $0,5 \mathrm{~g}+$ PCNB $1 \mathrm{~g}$ (pentaklórnitrobenzol) + Ökörepe $0,5 \mathrm{~g}+$ Agar-agar $20 \mathrm{~g}+$ Klórtetraciklin 0,05 g + Streptomicin $0,1 \mathrm{~g}$

\subsubsection{Tenyésztési módszer (Schnürer, 1993; Tanács} és mtsai, 1999)

- A búzaszemek felületén megtapadt gombák vizsgálata:

Minden búzafajtából és kezelési módból (11 cmes steril Petri-csészékbe) előre elkészített PCNBtáptalajra 50-50 szemet helyeztünk úgy, hogy a hasi barázda a táptalajba nyomódjon, de a táptalaj ne repedjen meg. A 72 órás $37{ }^{\circ} \mathrm{C}$-on történő inkubálás után mikroszkóp segítségével vizsgáltuk a felületen kialakult telepeket.

- A terméshéj alatt elhelyezkedő gombák vizsgálata:

A magokat $1 \%$-os neomagnolos oldattal fertőtlenítettük a termésfal felületén lévő gombák elpusztítására, majd háromszoros (steril desztillált vízzel történő) öblítést követő egy napos szikkasztás után az előző pont szerint kerültek a szemek táptalajra. Az inkubálási idő letelte után meghatároztuk a búzaszemek fertőzöttségét.

\subsection{A szermaradvány vizsgálatok körülményei}

Elektronbefogási detektorral felszerelt gázkromatográffal nagy érzékenységgel tudunk kimutatni halogén-tartalmú vegyületeket. A kezelésekre használt összehasonlító fungicideket gyári mintaként kaptuk a forgalmazott termékeknek megfelelöen adalékolva, összetett formában (Tango, Alert S, Artea, Amistar, Falcon, Juwel). Az összehasonlító mintákat GC-MS technikával vizsgáltuk az aktív komponensek vonatkozásában részletesen és a TIC (teljes ion kromatogram) is rögzítésre került. Néhány gabonaminta esetében GCMS mérés is történt, amivel megerösítettük párhuzamos ECD-vel mért eredményeinket.

A vizsgálatok első szakaszában (technikailag Tanács és mtsai, 1997b szerint) laborunk PACKARD 428 gázkromatográfjának elektronbefogási (EC) detektorát felújítottuk. A kapcsolt elektronikát 16 bites analóg/digital (A/D) átalakítóhoz illesztettük. PC-oldali programot írtunk az adatgyüjtésre. A gázkromatográf hőmérséklet programozóját ellenőriztük és alkalomszerűen korrigáltuk az eltéréseket. A gyüjtött adatokat az SPSS Peakfit programjával dolgoztuk fel. A mérések második fázisában DataApex rendszerre tértünk át, amivel a jelfeldolgozás hardver és szoftver háttere nagymértékben javult. A mérési eredmények megbízhatóságának nagymértékü növelésére a harmadik fázisban 30 m-es DB-5 fázisú (J\&W), illetve analóg kapilláris kolonnákkal szerelt, modern (EC és tömegérzékeny detektorral szerelt) HPgázkromatográfokon mértünk.

\subsubsection{Az állománypermetezésre használt fungicidek}

- TANGO: 125 g/l epoxikonazol + 375 g/l tridemorf

- JUWEL: $125 \mathrm{~g} / 1$ epoxikonazol + $125 \mathrm{~g} / \mathrm{l}$ krezoxim-metil

- FALCON 460 EC: $167 \mathrm{~g} / 1$ tebukonazol + 43 g/1 triadimenol $+250 \mathrm{~g} / \mathrm{l}$ spiroxamin

- $\quad$ ALERT S: $125 \mathrm{~g} / 1$ fluzilazol + $250 \mathrm{~g} / 1$ karbendazim

- ARTEA: $250 \mathrm{~g} / 1$ propikonazol + $80 \mathrm{~g} / 1$ ciproconazol

- KOLFUGO: 25\% karbedazim

- AMISTAR: $250 \mathrm{~g} / \mathrm{l}$ azoxistrobin

- BION: $50 \%$ bendikar

\subsubsection{Egyes fungicid maradványok kinyerése}

- FALCON (tebukonazol), ARTEA (ciprokonazol és propikonazol), TANGO illetve JUWEL (epoxikonazol) vonatkozásában az alábbiak szerint jártunk el (Tanács és mtsai, 1998):

Reanal gyártmányú oldószereket, A.R. tisztaságú acetont és n-hexánt használtunk. $10 \mathrm{~g}$ liszt vagy $10 \mathrm{~g}$ korpa került az extrakciós oszlopba, majd extrakció történt $75 \mathrm{~cm}^{3}$ acetonnal. Az extraktum bepárlása Rotadeszt-tel következett, majd a maradék felvétele 1 $\mathrm{cm}^{3}$ acetonban és ennek tárolása csiszolt dugós üvegben. Ebböl került $0,5 \mathrm{~cm}^{3}$ acetonos párlat $4 \mathrm{~g}$ Brockman V-ös $\mathrm{Al}_{2} \mathrm{O}_{3}$ oszlopra (meg kellett várni, 
amíg beszívódik), majd eluálás történt $15 \mathrm{~cm}^{3} \mathrm{n}$ hexánnal. Az eluátumot közel szárazra kell bepárolni, majd a maradékot $2 \mathrm{~cm}^{3}$ acetonnal felvéve újra bepárolni $\left(0,5 \mathrm{~cm}^{3}\right.$ alá), és kémcsőben (acetonnal) 0,5 $\mathrm{cm}^{3}$-re állítani a térfogatot, jól záróan tárolni $-20{ }^{\circ} \mathrm{C}$ on, gázkromatografálásig.

- ALERT (FLUZILAZOL) esetén a módszer hasonló mint előbb, de valamelyest módosul az alábbiak szerint (Tanács és mtsai, 1998):

$10 \mathrm{~g}$ liszt vagy korpa, $100 \mathrm{~cm}^{3}$ acetonnal extrakció, bepárlás Rotadeszt-tel, $1 \mathrm{~cm}^{3}$ diklór-metán, ebböl $0,5 \quad \mathrm{~cm}^{3} \quad \mathrm{Al}_{2} \mathrm{O}_{3}$ oszlopra $(4 \mathrm{~g}), 15 \mathrm{~cm}^{3} \mathrm{n}$ hexánnal extrakció, bepárlás $0,5 \mathrm{~cm}^{3}$-re, tárolás üvegdugós csőben $-20{ }^{\circ} \mathrm{C}$-on, gázkromatografálásig.

Brockman V-ös $\mathrm{Al}_{2} \mathrm{O}_{3}$ készítése: $100 \mathrm{~g} \mathrm{Al}_{2} \mathrm{O}_{3}$ (vízmentes Brockman I-es) $+15 \mathrm{~cm}^{3}$ nagytisztaságú víz, zárt rendszerben 4-6 óra rázatás után kész (jól záródóan tárolandó).

A minta sorrendet úgy alakítottuk ki, hogy a legnagyobb fungicid-kezelési dózissal kezdtünk és csak kimutatható mennyiségü szermaradvány esetén folytattuk a kémiai vizsgálatokat alacsonyabb dózisoknál.

\section{EREDMÉNYEK ÉS ÉRTÉKELÉS}

\subsection{Fungicidkezelt búzaminták ergoszterin tartalma mikrohullámú feltárás és folyadékkromatográfia (HPLC) alkalmazá- sával}

A HPLC-s ergoszterin kalibrációt 0-tól $3 \mu \mathrm{g}$-ig végeztük és $R^{2}=0,9997$ mellett az alábbi egyenes egyenlet írja le az eredményt: log [ergoszterin $\mu \mathrm{g} / \mathrm{ml}]=\left(\log \left[\mathrm{mOD}^{*} \mathrm{~s}\right]-\mathbf{0 , 3 9 6 3}\right) / \mathbf{0 , 9 6 0 8}$, ahol az $m O D{ }^{*} s$ az UV-detektor szolgáltatta abszorpciós jelből időegységre integrált érték. Az általunk kimutatható legkisebb ergoszterin mennyiség 5 ngnak adódott. A mérések eredményeit ennek alapján számszerüsítettük az 1. táblázatban.

A fungicid kezelések protokollja és a búzamintákból visszamérhető ergoszterin tartalom

\begin{tabular}{|c|c|c|c|}
\hline $\begin{array}{l}\text { Első kezelés(1) } \\
\text { (2-3 nódusz) }\end{array}$ & $\begin{array}{c}\text { Második kezelés(2) } \\
\text { (Kalászhányás, virágzás) }\end{array}$ & $\begin{array}{c}\text { GK MISKA* } \\
\text { Cergoszterin }_{\text {(ppm) }}\end{array}$ & $\begin{array}{c}\text { GK SÁRA* } \\
\text { C }_{\text {ergoszterin }}(\mathbf{p p m})\end{array}$ \\
\hline Kontroll & Kontroll & 1,05 & 7,09 \\
\hline Amistar 1,0 & - & 1,88 & - \\
\hline Amistar 0,6 & Amistar 0,4 & - & - \\
\hline Amistar 0,6 + U-46M 2,0 & Amistar $0,4+$ Kolfugo 1,5 & 0,72 & 1,39 \\
\hline Amistar $0.6+$ Bion $50 \mathrm{~g}$ & Amistar $0.4+$ Bion $30 \mathrm{~g}$ & 1.77 & - \\
\hline . & Tango 0,8 & 1,14 & 1,95 \\
\hline Tango 0,6 & Tango 0,6 & 1,39 & 1,07 \\
\hline- & Juwel 1.0 & 2.00 & - \\
\hline Juwel 1,0 & - & 3,61 & - \\
\hline Tango 0,6 & Juwel 0,8 & 7,09 & 1,62 \\
\hline- & Kolfugo 1,5 & 1,23 & 1,51 \\
\hline Falcon 0,6 & Falcon 0,6 & - & 0,88 \\
\hline- & Falcon 0,8 & 1,88 & 0,83 \\
\hline- & Alert 1,0 & 1,53 & 0,66 \\
\hline Artea $0,4+$ Bion $50 \mathrm{~g}$ & Artea $0,4+$ Bion $30 \mathrm{~g}$ & 2,30 & 0,63 \\
\hline Artea 0.5 & - & - & 0,76 \\
\hline- & Artea 0,5 & 3,80 & 0,91 \\
\hline
\end{tabular}

Table 1: The protocol of fungicide treatments and measured ergosterine content in two wheat varieties (*)

First treatment(1), Second treatment(2)

Nagyszámú gombaminta vizsgálata után francia kutatók alkalmasnak találták az ergoszterin mennyiségének mérésén alapuló penészbiomassza meghatározást gabonafélék minősítésére (Anonym, 1991). Ezen vizsgálatok eredményeképpen született meg a következő koncepció: amennyiben a minta ergoszterin tartalma $8 \mathrm{ppm}$ alatt van a vizsgált cereáliában a minősítése ,normal quality = normál”, ha pedig meghaladja a $12 \mathrm{ppm}$ értéket, akkor „doubtful quality = kétséges" minösítést kap. Hazánkban ergoszterin mennyiségén alapuló mikrobiológiai minőségellenőrző szabvány még nincs, bár a vizsgálatok előfeltételeit és eredményeit tekintve véleményünk szerint kívánatos volna.

A vizsgált búzaminták (GK Miska, GK Sára) tenyészidőszakában a meteorológiai viszonyok elsősorban a lehullott csapadék csekély mennyisége - nem kedveztek a penészgombák elszaporodásának. A vizsgált búzaminták ergoszterin tartalma kivétel nélkül a kimutatási határ környékére esett. Az adatok alapján a vizsgált búzaminták penészszennyezettsége valamint ergoszterin tartalma alacsony, a francia szabvány alapján „,normál” minősítést kapnának.

\subsection{A mikrobiológiai vizsgálatok eredményei}

Több búzafajta és két év (1999. és 2000.) eredményeit összesítjük az alábbiakban. A 2. táblázat a fajtajellemzéseket mutatja.

Az alábbi oszlop diagrammokon az átláthatóság érdekében az adatokat évenkénti bontásban, annak figyelembe vételével tüntettük fel, hogy a vizsgálat a gabonaszem felületi vagy belső gombafertőzöttségére 
irányult. Az 1-2. ábrák az eredményeket a fajták átlagában kifejezve szemléltetik.

A gombafajok megoszlását tekintve kiemelhetőek a nagy arányban megjelenö Fusarium és Alternaria, valamint a kisebb számban megfigyelhető, az „Egyéb” csoportba besorolt Penicillium, Mucor, Aspergillus, és Trichoderma fajok. Külön számoltuk azokat a magokat, amelyeken Alternaria és Fusarium együtt fordult elő. Ezek az ábrákon „Alt+Fus” jelzést kaptak. A fertőzésmentes szemek százalékos arányát a „Tiszta” csoport jelöli. A diagramok vízszintes tengelyén a gombafajok százalékos megoszlását, míg a függőleges tengelyen az alkalmazott fungicidek szerepelnek a felületi fertőtlenítés nélküli és a felületileg fertőtlenített szemek esetén egyaránt.

A vizsgált fajták agronómiai jellemzése

\begin{tabular}{|c|c|c|c|c|}
\hline & GK GARABOLY* & GK MISKA* & GK PETUR* & GK SÁRA* \\
\hline Minőség(1) & B1, B2 & $\mathrm{A} 2, \mathrm{~B} 1$ & $\mathrm{~A} 2, \mathrm{~B} 1$ & $\mathrm{~B} 1, \mathrm{~A} 2$ \\
\hline Fagytürés(2) & Jó(12) & Jó(12) & Jó(12) & Jó(12) \\
\hline Szárazságtűrés(3) & Jó- közepes(13) & Kiváló(14) & Jó(12) & Kiváló(14) \\
\hline Kalásztípus(4) & Szálkás(15) & $\operatorname{Tar}(16)$ & $\operatorname{Tar}(16)$ & $\operatorname{Tar}(16)$ \\
\hline Érésidő(5) & Korai(17) & Középérésü(18) & Középérésü(18) & Korai(17) \\
\hline Magasság $(\mathrm{cm})(6)$ & $90-95$ & $80-90$ & $80-90$ & $80-90$ \\
\hline Fusarium ellenállóság(7) & Közepes(19) & Közepes(19) & Jó(12) & Közepes(19) \\
\hline Herbicid érzékenység $(8)$ & Nem érzékeny(20) & Nem érzékeny(20) & Nem érzékeny(20) & 2,4-D, isoproturon, dikamba \\
\hline Állóképesség(9) & Jó(12) & Jó(12) & Kiváló(14) & Kiváló(14) \\
\hline Vetésidö(10) & X. 05-20 & X. 05-20 & X. $10-30$ & X. 05-20 \\
\hline Csíraszám $\mathrm{db} / \mathrm{m}^{2}(11)$ & $550-600$ & $550-600$ & $500-600$ & $550-600$ \\
\hline
\end{tabular}

Table 2: Agronomic characterization of the investigated strains (labelled by *)

Baking quality(1), Frost resistance(2), Drought tolerance(3), Head type(4), Earliness(5), Height(6), Resistance to scab(7), Herbicide sensitivity(8), Lodging resistance(9), Sowing date(10), Seed/m²(11), Good(12), Good-medium(13), Excellent(14), Awned(15), Awnless(16), Early(17), Medium early(18), Medium(19), Tolerant(20)

\section{1. ábra: Fungicid állománykezelések hatása búzaszemek felületi gombafertőzöttségére 4 fajta átlagában} (GK Garaboly, GK Miska, GK Petur, GK Sára)

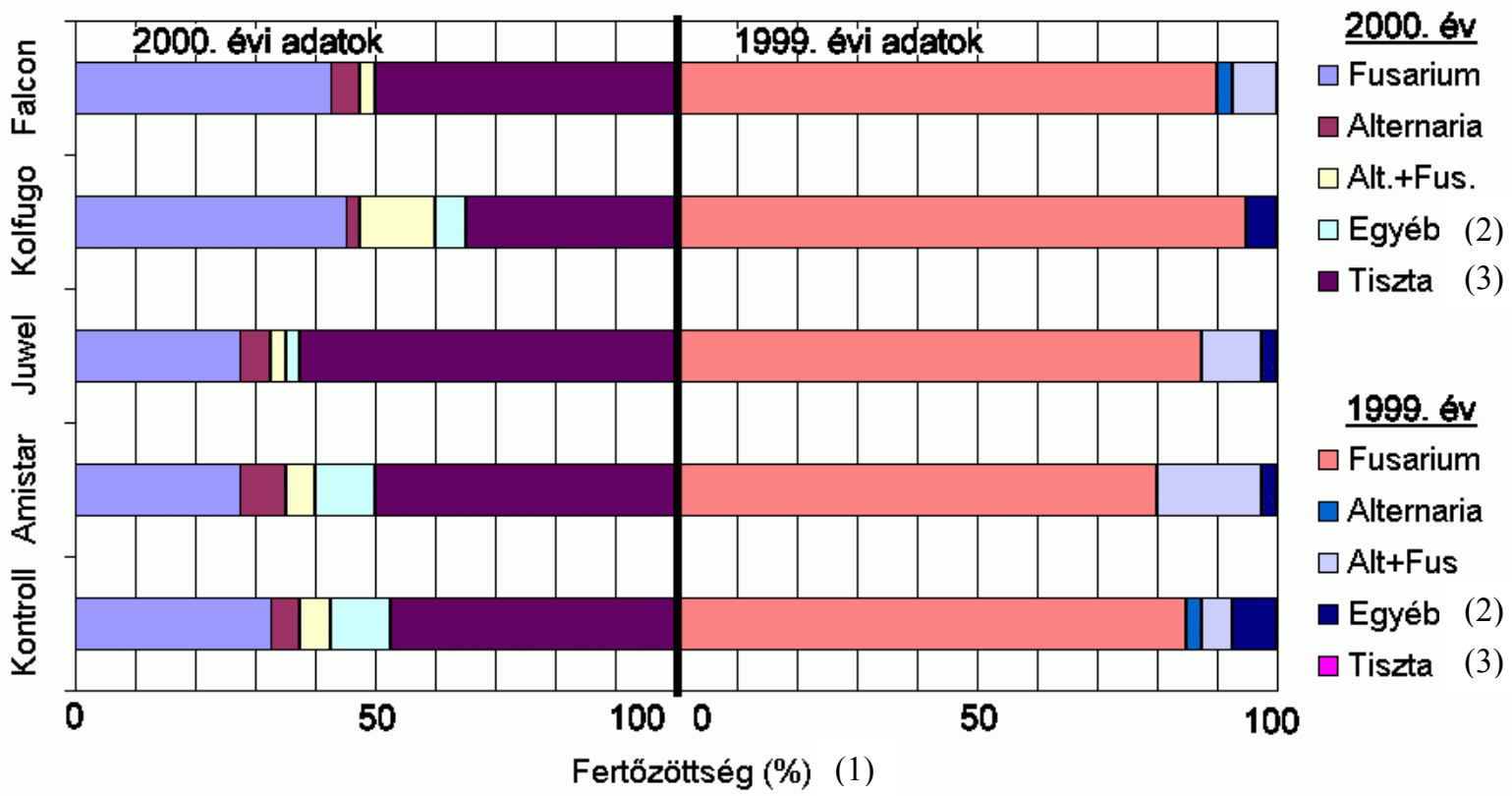

Figure 1: Peripherial fungal infections of fungicide treated cereals in average of 4 varieties (year 2000 and 1999) Infected in percent (\%)(1), Else(2), Uncontaminated(3)

4 fajta átlagában, a 2000-es kezelések során alkalmazott fungicidek eredményességét ábrázolja a diagram (1. ábra, balra) a felületi mikroflóra vizsgálata során. A Kontroll csoport esetében a Fusarium 30\%-ban, az Alternaria 5\%-ban, Alternaria
+ Fusarium 5\%-ban jelentek meg, az Egyéb fajok aránya $10 \%$, a Tiszta szemek aránya $50 \%$. Az Amistar alkalmazásakor a Fusarium fertőzöttség 25\%-os volt, az Alternaria 7\%-os fertőzöttséget mutatott. Az Alternaria + Fusarium 3\%-ban volt 
fertőzött. Az Egyéb fajok fertőzöttsége 10\%, a Tiszta szemek aránya 55\%. A Juwel fungicid alkalmazásakor a Fusarium 25\%-ban, az Alternaria 5\%-ban fertözött. Az Alternaria + Fusarium 2\%-ban, az Egyéb fajok 2\%-ban jelentek meg a felületen. A Tiszta szemek aránya $66 \%$-os. A Kolfugo esetében a Fusarium fertőzöttség 42\%-os volt. Az Alternaria 2\%-ban, az Alternaria + Fusarium 14\%-ban jelent meg. Az Egyéb fajok 4\%-ban fertőztek. A Tiszta szemek aránya 38\%. A Falcon alkalmazásakor a Fusarium fertőzöttség 40\%-os. Az Alternaria fajok 5\%-ban, az Alternaria + Fusarium 2\%-ban fertőztek. A Tiszta szemek aránya 53\%-os. A Kontrollhoz viszonyítva az Amistar és a Juwel elnevezésű fungicidek voltak a leghatékonyabbak.

4 fajta átlagában, az 1999-es kezelésekben alkalmazott fungicidek eredményességét ábrázolja a diagram (1. ábra, jobbra) a felületi mikroflóra vizsgálata során. A Kontroll csoport esetében nem alkalmaztak fungicides kezelést, így a Fusarium
$82 \%$-ban, az Alternaria 2\%-ban, Alternaria + Fusarium 6\%-ban és az egyéb fajok 10\%-ban jelentek meg. Az Amistar hatásosan csökkentette a Fusarium arányát, mert annak megjelenési aránya $78 \%$-os, az Alternaria + Fusarium aránya $20 \%$ és az egyéb fajok 2\%-ban jelentek meg. A Juwel alkalmazásakor a Fusarium 85\%-ban, Alternaria + Fusarium 10\%-ban és az egyéb fajok 5\%-ban fertőzték a búzaszemet. A Kolfugo fungicid alkalmazásakor a Fusarium aránya 93\%-os, az Egyéb fajoké $7 \%$-os a szem felületén. A Falcon alkalmazásakor a Fusarium fertőzöttség $85 \%$ volt, míg az Alternaria fajok 2\%-ban fertőztek és az Alternaria + Fusarium 10\%-ban jelent meg. A neomagnollal nem kezelt szemekkel végzett kísérlet során azt tapasztaltuk, hogy a Kontrollhoz viszonyítva a Fusarium fertőzést az Amistar és a Juwel nevü fungicid csökkentette a leghatékonyabban.

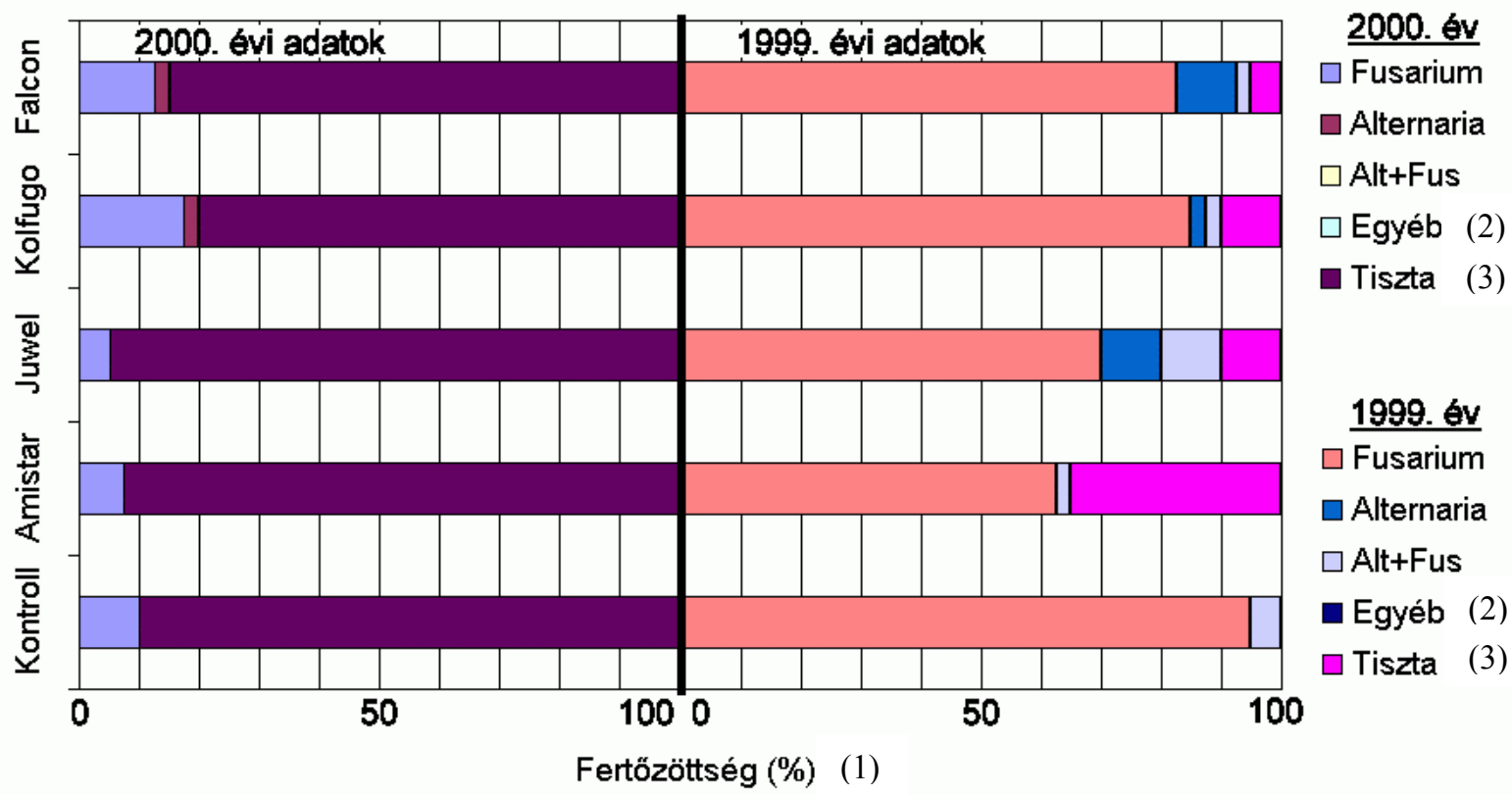

Figure 2: Internal fungal infections of fungicide treated cereals in average of 4 varieties (year 2000 and 1999) Infected in percent (\%)(1), Else(2), Uncontaminated(3)

A 2. ábra baloldali diagramja a 2000-es év adatai alapján mutatja (neomagnolos kezelés után) a termésfalon belüli gombákat. A Kontroll esetében $8 \%$ a Fusarium és $92 \%$ a Tiszta szemek aránya. Az Amistar fungicid alkalmazásakor a Fusarium 6\%ban jelent meg. A Tiszta szemek aránya 94\%. A Juwel esetében 4\%-os Fusarium fertőzöttség mutatkozott. A Tiszta szemek aránya 96\%. A Kolfugo alkalmazásakor 16\%-os a Fusarium, 2\%-os az Alternaria fertőzöttség. A Tiszta szemek aránya $82 \%$. A Falcon esetében a Fusarium fertőzöttség 10\%. Az Alternaria 2\%-ban jelent meg. A Tiszta szemek aránya $88 \%$. A kontrollhoz viszonyítva az Amistar és a Juwel volt a leghatékonyabb.
$\mathrm{Az}$ 1999-es évben neomagnollal felületileg fertőtlenített szemek esetében a termésfalon belüli gombák vizsgálati eredményeit mutatja a 2. ábra, jobboldala. A Kontroll csoport esetében a Fusarium fertőzöttség 92\%-os, Alternaria + Fusarium 8\%-os volt. Az Amistar esetében $60 \%$-os volt a Fusarium fertőzöttség. Az Alternaria + Fusarium 2\%-os arányban jelent meg. A Tiszta szemek 38\%-ban jelentek meg. A Juwel fungicid alkalmazásakor a Fusarium 68\%-ban jelent meg. Az Alternaria 11\%ban, az Alternaria + Fusarium. 10\%-ban fertőzött. A Tiszta szemek aránya $11 \%$-os volt. Kolfugo alkalmazásakor a Fusarium $82 \%$-os, az Alternaria $2 \%$-os és az Alternaria + Fusarium is $2 \%$-os 
arányban jelent meg. A Tiszta szemek aránya 14\%. A Falcon esetében a Fusarium $80 \%$-ban, az Alternaria 10\%-ban jelent meg. Az Alternaria + Fusarium 2\%ban fertőzött. A Tiszta szemek aránya 8\%. A kontrollhoz hasonlítva a neomagnolos vizsgálat esetében az Amistar és a Juwel fungicidek voltak a leghatékonyabbak.

A különböző fajták és az egyes kezelések hatásmechanizmusát tekintve az eredményeket (itt nem részletezett módon varianciaanalízissel) elemezve nem mutathatóak ki szignifikáns eltérések, de a két év meteorológiai különbségének tulajdoníthatóan (ami a csapadék mennyiségében tér el) erősen eltérő adatok adódnak. 50-50 elemi mintát vizsgálva, 1999-ben a fusariumos szemek száma 31 és 47 közé esett, amely érték 2000-ben 15 és 21 közötti darabszámra csökkent. A termesztés évét véve alapul a különbség 95\%-os szinten szignifikáns.

\subsection{Az alkalmazott, halogén-tartalmú fungicid maradványok vizsgálata gázkromatográfiával (GC)}

Példákat mutatunk a 3. és 5. ábrán arra, hogy a halogénezett fungicidek elektronbefogási detektorral (ECD) kimutatható spektrumát az ismeretlen összetételü minták rögzített jeleire vetítettük az esetleges átfedések láttatására, adott komponens(ek) előfordulásának jelzésére.

\section{3. ábra: TANGO komponensek vizsgálata ECD detektorral}

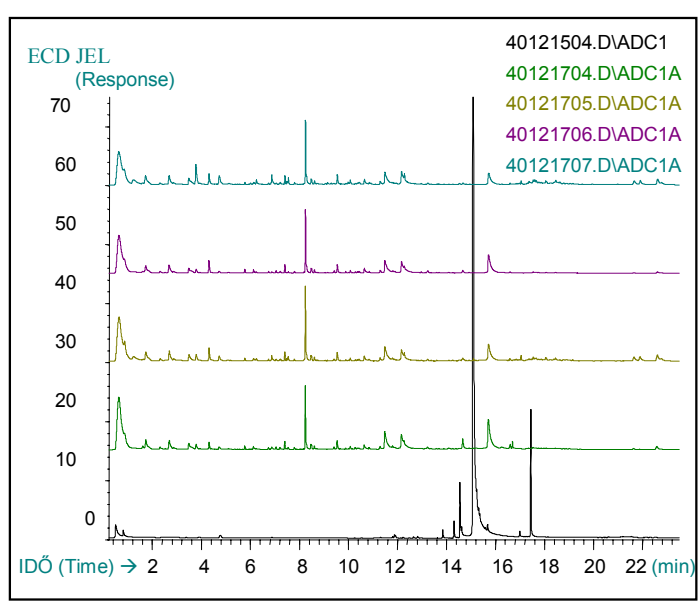

Jelmagyarázat (ECD-görbék alulról felfelé): Tango alapanyag, Tango kezelt GK-Sára liszt, illetve korpa és GK-Miska liszt, illetve korpa kivonatok.

Figure 3: ECD studies on Tango composition

(ECD curves from below, upwards): Tango base material, Tango treated GK-Sara flour and bran followed by GK-Miska flour and bran extacts.

A mintákat érintő GC-MS vizsgálatokra a GKSára liszt frakciókat választottuk, mivel ezeket már korábban is vizsgálták egyszerübb módszerrel (Tanács és mtsai, 1997a, 1997b, 1997c, 1998). Példaként a JUWEL fungiciddel összefüggésben kapott teljes ion görbéket mutatunk (4. ábra). Hasonlóan negatív eredményeket adtak más (2000ben alkalmazott) fungicidek is.

\section{4. ábra: GC-MS teljes ion görbék}

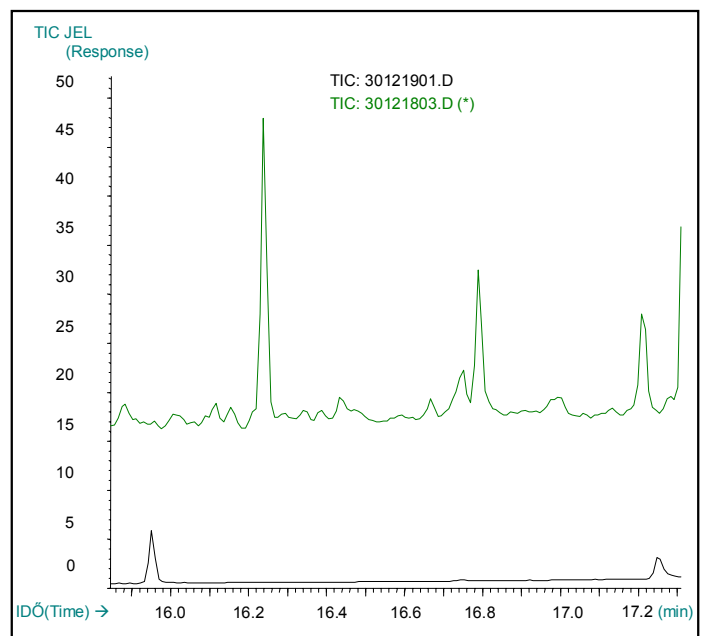

Jelmagyarázat: teljes ion görbék (TIC) a JUWEL alapanyag (alul) és a JUWEL kezelt GK-Sára liszt kivonat (felül) GC-MS vizsgálata során.

Figure 4: GC-MS total ion curves

Juwel base material (below), Juwel treated GK-Sara flour extract (on top).

Falcon kezelt kétféle búzának liszt és korpa frakcióit vizsgáltuk az 5. ábra szerint. Ellenőrzésképpen, nyomokban (fungiciddel eredetileg nem-kezelt) liszteket szennyeztünk Falconnal. A laboratóriumi mintákat a szabadföldiekkel azonos eljárásnak vetettük alá és vizsgáltuk. A szándékosan szennyezett lisztek extraktumából a jelzett fungicid egyértelmüen kimutatható (6. ábra).

5. ábra: FALCON komponensek vizsgálata ECD detektorral(1)

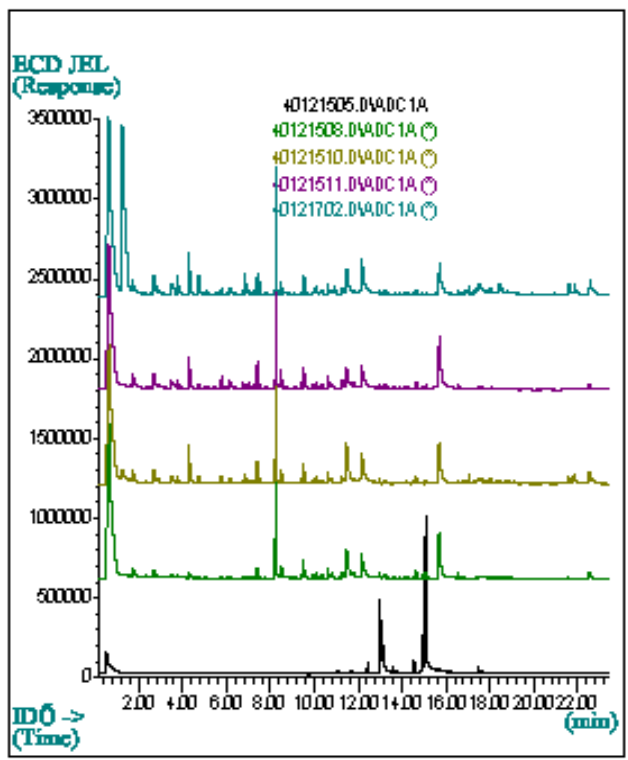

Jelmagyarázat (ECD-görbék alulról felfelé): FALCON alapanyag, FALCON kezelt GK-Sára liszt, illetve korpa és GK-Miska liszt, illetve korpa kivonatok.

Figure 5: ECD studies on Falcon components (curves from below): Falcon base material; Falcon treated GKSara flour and bran; Falcon treated GK-Miska flour and bran. 


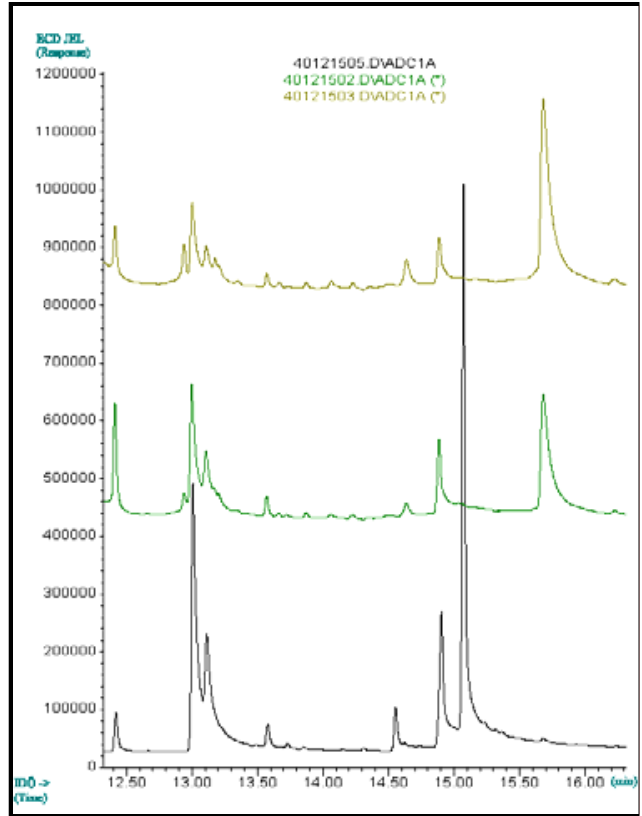

Jelmagyarázat: alul - Falcon (gyári kiszerelés), felül - nyomokban Falconnal (ellenőrzésképpen, szándékosan) szennyezett két különbözö kontroll liszt kivonata.

Figure 6: ECD studies on Falcon components

(below): Falcon (factory originalc), (upper) two different flour samples, intentionally contaminated with a small amount of Falcon.

Azonos vizsgálatokat végeztünk ARTEA és ALERT fungicid kezelt mintákon is. Minden minta negatívnak adódott, egyetlen vizsgált mintában sem találtunk fungicideket. A tavaszi fungicid kezelések szermaradvány nyomai november végére már biztosan a kimutathatósági szint alá csökkennek.

Jelen munkát az FVM ,Technológiai fejlesztési kutatások" témakörben támogatta (65-d3/2000).
Anonym (1991): Francia szabadalom: Détermination de la teneur en ergostérol. NF V 18-112.

Schnürer, J. (1993): Comparison of methods for estimaing the biomass of three food-borne fungi with different growth patterns. Appl. Environ. Microbiol. 59. 552-555.

Schnürer, J. (1995): Fungal identification techniques. Proceedings from the workshop in Barcelona, 5 to 8 april 1995

Szabó, G.-Rigó, K.-Téren, J.-Varga, J. (2000): Predictive modelling of fungal contamination in plant products using microwave-assisted ergosterol extraction method. $3^{\text {rd }}$ International Congress of Model IT. Belgium, Leuven Katholike University. 12-15 September 2000

Tanács L.-Matúz J.-Fehér L.-Gerő L.-Hampel Gy. (1999): Peszticid kezelések hatása az őszi búzák sütőipari tulajdonságaira és mikroflóra alakulására. Agrárfőiskolák Szövetségének Tudományos Közleményei, 20. 3. 82-97.

Tanács L.-Szabó G.-Csatlós I.-Dankó S. (1997a): Fungiciddel kezelt őszibúza szermaradvány-vizsgálata. Növénytermelés, 46. 4. 383-399.

Tanács, L.-Csatlós, I.-Matúz, J. (1997b): Study of fungicide residues in the grain of fungicide-treated wheats. I. Cyproconazole- and carbendazime-based fungicides. Cereal Research Communications, 25. 4. 993-1000.

Tanács, L.-Matúz, J.-Csatlós, I.-Gerő, L. (1998): Study of fungicide residues in the grain of fungicide-treated wheats. III. Flusilazole, cabendazime, tebuconazole and triadimefon-based fungicides. Cereal Research Communications, 26. 3. 329-336.

Tanács, L.-Szabó, G.-Csatlós, I.-Matúz, J. (1997c): Study of fungicide residues in the grain of fungicide-treated wheats. II. Propiconazole- and bromuconasole-based fungicides. Cereal Research Communications, 25. 4. 1001-1006.

Young, C. J. (1995): Microwave-assisted extraction of the fungal metabolit ergosterol and total fatty acids. J. Agric. Food Chem. 43. 2904-2910. 